\title{
Communicating Corporate Social Responsibility in the post mandate period: Evidence from India
}

\author{
Nayan Mitra ${ }^{1 *}$, Asif Akhtar $^{2}$ and Ananda Das Gupta ${ }^{3}$
}

\begin{abstract}
The concept of Corporate Social Responsibility (CSR) underwent a overhaul in India for certain large, stable companies post the passing of the Companies Act, 2013. It transited from being a voluntary, sporadic exercise to mandated, objective, structured, transparent and accountable compliance - not only to the Government, but also to the other stakeholders and most importantly, to the Companies themselves. As a result, Corporate Communication on CSR became extremely relevant. Moreover, study of mandated CSR (here, under the Section 135 and Schedule VII of the Companies Act, 2013) also became a new area for knowledge creation. Although, much research has been done in the past to assess the relationship of CSR Communication with CSR and study the relationship of CSR with regards to Firm Performance, yet, this investigation remains the first empirical study done in the post-mandate period between the years 2015-2017, barely two years since the Act came into existence.
\end{abstract}

Keywords: India CSR, Corporate social responsibility, CSR communication, Mandated CSR, Section 135, Schedule VII, India, Empirical study, CSR mediator, Firm performance, Emerging economies, Intangible benefits, Reputation, Image

\section{Introduction}

CSR communication has gained a momentum in India in recent times (2014 onwards), not only because the firms feel strongly to communicate their CSR efforts, but also, because it is mandated by the Section 135 of the Companies Act, 2013 (Appendix 1) that requires the Board of the stipulated Companies to: "after taking in account the recommendations made by the CSR Committee, approve the CSR policy for the Company and disclose the contents of such Policy in its report and also place it on the company's website, if any, in such manner as may be prescribed." This act of including CSR Communication within the statute has made it not only more relevant, but also more serious. However, this "process of communicating the social and environmental effects of organizations' economic actions to particular interest groups within society and to the society at large" (Gray et al. 1996; Wang 2013) is not new.

\footnotetext{
* Correspondence: mitra.nayan@gmail.com

${ }^{1}$ Independent Developmental Consultant, Kolkata, India

Full list of author information is available at the end of the article
}

Different scholars at different times have recognised different philosophies of various Companies for communicating their CSR efforts. Kotler and Lee 2005 observe that while some recommend "don't be shy," others have a company policy to " let others do the talking." Whatever be the philosophy, a CSR Communication plan can minimize 'company anxiety' regarding CSR communications as over-promising or declarations of rightness and good intentions that could cause mistrust of consumers and stakeholders creating the opposite effects from those expected (Das Gupta 2012). Yet, any discussion on CSR or its Communication will remain incomplete unless it's effect on the firm performance is gauzed. After all, the purpose of any business is to maximise profit.

\section{Literature review}

The concept of CSR has had a long and diverse history in extant literature. Murphy (1978) classified four broad CSR eras that embraced the period before and after the 1950s, as follows (Table 1). Infact the year 1950 is popularly known as the beginning of the modern era in CSR. 
Table 1 Four Broad CSR Eras Before and After Year 1950 till 1978

\begin{tabular}{ll}
\hline Period & Role of CSR \\
\hline up to the 1950s & $\begin{array}{l}\text { 'philanthropic' era, in which companies donated to charities more than anything else } \\
\text { 'awareness' era, characterized by more recognition of the overall responsibility of business } \\
\text { and its involvement in community affairs } \\
\text { 'issue' era, in which companies began focusing on specific issues such as urban decay, racial } \\
\text { discrimination, and pollution problems }\end{array}$ \\
$\begin{array}{l}\text { 1974-8 and, continuing beyond } \\
\text { actions to address CSR issues }\end{array}$ \\
\hline
\end{tabular}

Source: Adapted from Carroll 2008

In 1979, Carroll proposed a four-part definition of CSR which was embedded in a conceptual model of corporate social performance (CSP), where he defined the social responsibility of businesses as encompassing the economic, legal, ethical, and discretionary expectations that society has of organizations at a given point in time.

During the 1980s, a 'social responsibility agenda for the 1980s' was set forth by Frederick (2006) that closely corresponds with, or was slightly ahead of, business concerns and practices during this period.

The prominent themes which continued to grow and take center stage in the 1990s included the following: corporate social performance (CSP), stakeholder theory, business ethics, sustainability, and corporate citizenship (Carroll 2008). However, a careful analysis of these definitions reveal that they are more in the nature of micro-definitions. These micro-definitions, more often than not, fall within the macro concepts of CSR, that "reflects three distinct, discontinuous perspectives, namely, shareholder value, societal value and stakeholder value" (Rath \& Gurtoo, 2012).

However, Stanaland et al. (2011) opined that the perceptions of a company's attitude toward CSR are influenced by its corporate marketing efforts like its communication (Schiefelbein 2012; Mitra 2015). Hence, regardless of the philosophic perspectives on corporate recognition, developing a communications plan for the initiative is a best practice (Kotler and Lee 2005).

\section{CSR communication and corporate social responsibility}

In a climate that is arguably marked by more informed publics and a critical media, companies are facing more clearly articulated expectations from customers and consumers regarding their contributions to sustainable development, which puts pressure on them to maintain transparency and be proactive in communicating with its publics (Ghosh 2014; Mitra 2015). CSR Communication objectives should, therefore, signal desired audience outcomes; e.g., increase in awareness, concern, participation, and/or individual behaviour change (Kotler and Lee 2005; Mitra 2015). This shows that, firms that undertake CSR activities with a strategic intent (intention to gain) should initiate a respectful and honest communication with their customers (Noland and Phillips 2010; Isaksson 2012).

Infact, Sethi (2014), Mitra (2015) feels that CSR reports, Business Responsibility Reports and Sustainability Reports are instruments to manage reputation; therefore should be the essence of a robust communication strategy.

\section{Corporate social responsibility and firm performance}

On the other hand, Shaista and Sara (2014), evaluated and found a positive correlation between CSR and organizational performance. Evidence from research indicates that CSR is associated with profitability, and contributes to employee commitment and customer loyalty (Fraedrich and Ferrell 2008; Friday 2015). This profitability can be measured in terms of financial performance and non-financial performance. While financial performance calculates only financial measures; non-financial performance tries to measure the intangible benefits for the company such as corporate reputation and image (Schwaiger 2004) increased employee motivation (Epstein and Roy 2001), improved brand image (Heal 2005) and the like (Mishra and Suar 2010). Today, business performance is no longer measured only in terms of the balance sheet value, but by the positive impact of business on the shareholders and other relevant publics (Friday 2015). Infact, there has been an abundance of management accounting literature highlighting the inadequacies of relying primarily on financial performance measures for performance measurement and evaluation (e.g., Kaplan 1984; Bromwich and Bhimani 1994; Abdel-Maksoud et al. 2005; Lau and Martin-Sardesai 2012). By filling in the gaps left by financial accounting, nonfinancial measures promise to complete the picture of a company's performance (Ittner and Larcker 2003).

As a matter of fact, within the past few years, the importance of intangible assets in general and the significance of corporate reputation in particular have grown rapidly (Schwaiger 2004). Taking into consideration that companies showing strong reputation have better access to capital markets, which decreases capital costs (Beatty and Ritter 1986) and lowers procurement rates (Schwalbach 2000), it 
is obvious that a company's profitability ceteris paribus grows with a better reputation (Schwaiger 2004).

Generally construed, reputation is the overall estimation of a company by its stakeholders (Fombrun 1996). A favourable reputation can be a strategic resource that improves performance (Hall 1992; Deephouse and Ourso 1997). Infact, McGuire et al. (1990) provide evidence indicating that the reputation-performance effect may operate in both directions: a firm's financial performance affects its reputation, but its reputation also affects its performance (Roberts and Dowling 1997). Infact, it has also been demonstrated that investing in a positive CSR image and reputation aligns with the ideas of relationship management and allows companies to reach their commercial goals more easily (Perez and Rodríguez del Bosque 2013).

This Literature review from Section "CSR communication and corporate social responsibility and Corporate social responsibility and firm performance" forms the basis of the following hypothesis:

\section{$H_{1}$ : There is a significant relationship between CSR Communication and (Variable) Corporate Social Responsibility.}

$\mathrm{H}_{2}$ : There is a significant relationship between (Variable) Corporate Social Responsibility and Firm Performance.

\section{Research gaps}

Literature review further pointed out a distinct gap in research in an emerging economy context, as

- Current literature on CSR focuses heavily on instances from developed western markets (Eberhard-Harribey 2006, Knights and O'Leary 2006, Vuontisjärvi 2006, Habisch et al. 2005, etc.), and the replicability of these findings on the emerging markets, e.g., of Asian countries, is lacking (Khan, 2008);

- Challenges faced by the developing countries with respect to CSR are different as compared to challenges faced by the developed countries (Ghosh 2014; Chatterjee and Mitra 2017).

So, even within emerging economies, India was selected as there has been little emphasis on CSR researches in Asian developing countries as compared to the West' (Ghosh 2014; Erden and Bodur 2013). Moreover, in the management literature, only recently, some work has been done on CSR in Asian developing countries (Chapple and Moon 2005; Erden and Bodur 2013).
Thus, a research adaptation in India is justified, as further literature review reveals that:

i). Empirical evidence from CSR research in India suggests that there are differences with regard to India's perceptions, operationalization and expectations of CSR practices when compared to those of the West (Kumar et al. 2001; Mohan 2001; Ghosh 2014).

ii). India largely retains its own characteristics, adopting only some aspects of global mainstream CSR (Ghosh 2014).

iii). Researches on mandated CSR are a new field of study as CSR statute in India, itself, has been introduced only in the year 2013 and has come into effect from Financial Year 2014-15 (Chatterjee and Mitra 2017).

iv). Lack of empirical research post the passing of the mandate (Chatterjee and Mitra 2017).

These research gaps led to this empirical investigation that was conducted between the years 2015-2017, barely 2 years since the CSR mandate came into force in India and concerns itself solely with the new area of study, mandated CSR. By using the term 'mandated CSR' in this research, we refer to the Section "Introduction"35 of the Companies Act 2013 (Appendix 1) that was introduced in India after replacing the 57 years old Companies Act of 1956.

\section{Research objectives}

Thus, from the research hypothesis and the research gaps, the objectives of this research can be framed. The objectives, therefore, are mainly to establish the relationship between CSR Communication and (Variable) Corporate Social Responsibility; and between (Variable) Corporate Social Responsibility and Firm Performance. Additionally, the mediating role of (Variable) Corporate Social Responsibility between CSR Communication and Firm Performance has been analysed; and (Variable) Corporate Social Responsibility strategy for large Indian firms in the context of their firm performance has been suggested/ proposed.

\section{The conceptual framework}

In order to attain these objectives, the conceptual model or the theoretical structure of assumptions, principles, and rules that holds together the ideas comprising a broad concept (Conceptual framework n.d.), in this research is as follows (Fig. 1):

The variables in the above model can be understood with the help of Table 2. In the Conceptual Model (Fig. 1) above, it is observed that (Variable) 


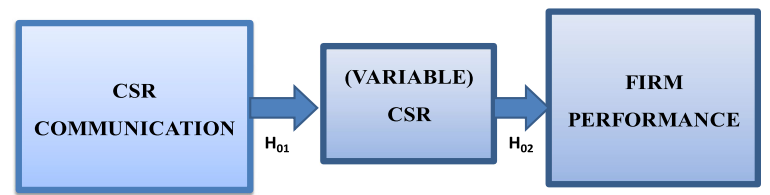

Fig. 1 Conceptual Research Model, Source: Researchers' Own

CSR acts both as a dependent as well as an independent variable (Table 2).

In other words, in this research, (Variable) Corporate Social Responsibility (VCSR) is a mediator variable, that is, the variable that causes mediation between the dependent and the independent variables. The different abbreviations and connotations used to denote the variables of the Conceptual model are as follows (Table 3):

Thus, the (Variable) CSR used in this research is different from that of the CSR in the developed countries and contributes to improving the governance, social, ethical, labour, environmental conditions of the developing countries. Here, the context is India.

Moreover, in this research, Firm Performance will measure only the intangible or non-financial firm performance like that of reputation and image through the eyes of one of its key stakeholders (employees) with respect to its competitors.

\section{Research methodology}

This study is a part of the larger and more indepth investigation of Mitra's (2017) research, titled 'Corporate Social Responsibility: A study of Strategic Management and Performance in Large Indian Firms' which is an adaptation of Isaksson's (2012) research (with due permission), titled 'Corporate Social Responsibility: A study of Strategic Management and Performance in Swedish Firms.' Thus, since this study has already been done in part in Sweden, this is a conclusive research, that 'tests and authenticates the propositions revealed by exploratory research' (Chawla and Sondhi 2011). Here, the exploratory research is Isaksson's 2012 empirical research, that has been developed using a qualitative research as a base. However, just to assess the content validity of the reconstructed instrument, a pilot study was done among 5 subject experts (3 Academicians and 2 practitioners). Their inputs have guided the research not only during the pilot study in finalizing the questionnaire, but also in

Table 2 Key Constructs of the Study

\begin{tabular}{lll}
\hline Stage & Independent variables & Dependent variable \\
\hline 1 & CSR Communication & VCSR \\
2 & VCSR & Firm Performance \\
3 & CSR Communication & Firm Performance
\end{tabular}

Source: Researchers' Contribution firming up the research methodology, research analysis and discussion phase.

The research design can be understood with the help of the following Fig. 2:

However, at every stage, secondary data search formed the basis of comprehension and corroboration of quantitative findings.

\section{Sampling design}

In order to identify the right database to classify the large Indian firms, a literature review of the previous CSR researches in India was done that divulged the use of certain repositories, some of which have been documented in Table 4.

On analysing the above-mentioned databases, it was found that Prowess suffers from many limitations, for instance, there are many firms operating in the Indian Automobile industry which are not listed in the Prowess database. Moreover, it is known that there are firms within this sector which control the entire production of certain components and such information disappears because of the aggregation problem of industrial classification adopted by the Prowess database. This is true in the case of many other sectors such as drugs and pharmaceutical industry (Beena 2014). Hence, the Prowess database was eliminated from our consideration.

On the other hand, a correspondence with the representative of 'Karmayog.org'(on January 8, 2015) confirmed that their definition of 'largest company' are based on 500 largest companies listed in BSE based on their sales; however, the Karmayog Rating has not been updated post 2010. Hence, the Karmayog CSR rating was also eliminated from our consideration.

Moreover, literature review of all the researches mentioned in Table 4 revealed that the BSE/ NSE database was more suitable for qualitative investigations that uses secondary data analysis and not so much for quantitative researches using interview techniques. This belief was re-inforced by the five subject experts ( 3 academicians and 2 practitioners). Hence, there was a dilemma in going ahead with this database.

As this debate was going on, as to which database to use, India was going through a reformation in its CSR arena. India was speaking the language of not only 'large' companies, but also, 'large, stable companies', (Chatterjee and Mitra 2017) who had to spend $2 \%$ of their average net profits made during the three immediately preceding financial years, in pursuance of its CSR policy, under the Companies Act of 2013. Keeping this transformation in view, the criteria for inclusion in the research was narrowed down to the selection criteria as laid down by the Government under Section 135 of the Companies Act, 2013. The rationale behind this selection was that these are the Companies, who are not only large in a certain 
Table 3 Guide to Abbreviations and Connotations of Variables Used in Conceptual Model

\begin{tabular}{lll}
\hline Variables & Abbreviations & \begin{tabular}{l} 
Connotation in this conceptual model \\
\hline CSR Communication
\end{tabular} \\
VCOM & $\begin{array}{l}\text { "The process of communicating the social and environmental effects of organizations' economic actions to } \\
\text { particular interest groups within society and to the society at large" (Gray et al. 1996). } \\
\text { "Variable) Corporate Social } \\
\text { Responsibility }\end{array}$ \\
Firm Performance & $\begin{array}{l}\text { Thical, labour, environmental conditions of the developing countries in which they operate, while remaining } \\
\text { sensitive to prevailing religions, historical and cultural contexts" (Visser 2008). Here, the context is India. }\end{array}$ \\
VFP & $\begin{array}{l}\text { Non-financial performance; "intangible benefits for the company such as corporate reputation and image" } \\
\text { (Schwaiger 2004). }\end{array}$
\end{tabular}

Source: Researchers' Compilation

financial year, but also large and stable over the last 3 years.

A list of these Companies was received from the Indian Institute of Corporate Affairs (IICA) repository of the 'Top 2500 CSR Companies' CSR Crawler Master Database in April, 2016, which formed the sampling frame of the research. These companies covered a wide range of Indian industries including automobiles, pharmaceuticals, consumer goods, power, energy, oil and natural gas, Information technology, and service sector. Moreover, all of these Companies fell within the CSR statute under the Company's Act, 2013 (and hence, the stipulated criteria required for this research).

\section{Tools for data collection}

Data has been collected from both primary source with the help of a questionnaire as well as secondary source to validate research hypotheses. The survey instrument (questionnaire) was also developed based on literature review, where the items measuring the constructs in the conceptual model has been influenced by the existing literature and then formatted in a consecutive order, with the exception of the CSR Index.

In India, there is an absence of a CSR Index. Only recently, "on September 23, 2013, BSE Ltd. (formerly known as the Bombay Stock Exchange Ltd.) and the Indian Institute of Corporate Affairs has signed a Memorandum of Understanding (MoU) in Mumbai to work collaboratively to develop a CSR Index, which will be the driver for CSR practices for the Indian Corporate World and an ideal option for investors to put their money for 'responsible investment"' (BSE India 2015). It is still under process. Till the time, when the official CSR Index is formulated, the catalogue of Schedule VII under the Company's Act, 2013 has been used, that closely substantiates the Index for CSR Research in India.

The pitfalls of the questionnaire method were checked by an iterative process of pretesting and pilot survey. This ensured scientific rigour and resulted in a robust research instrument.

While developing the items, following were given emphasis: ensuring readability of each item; preventing

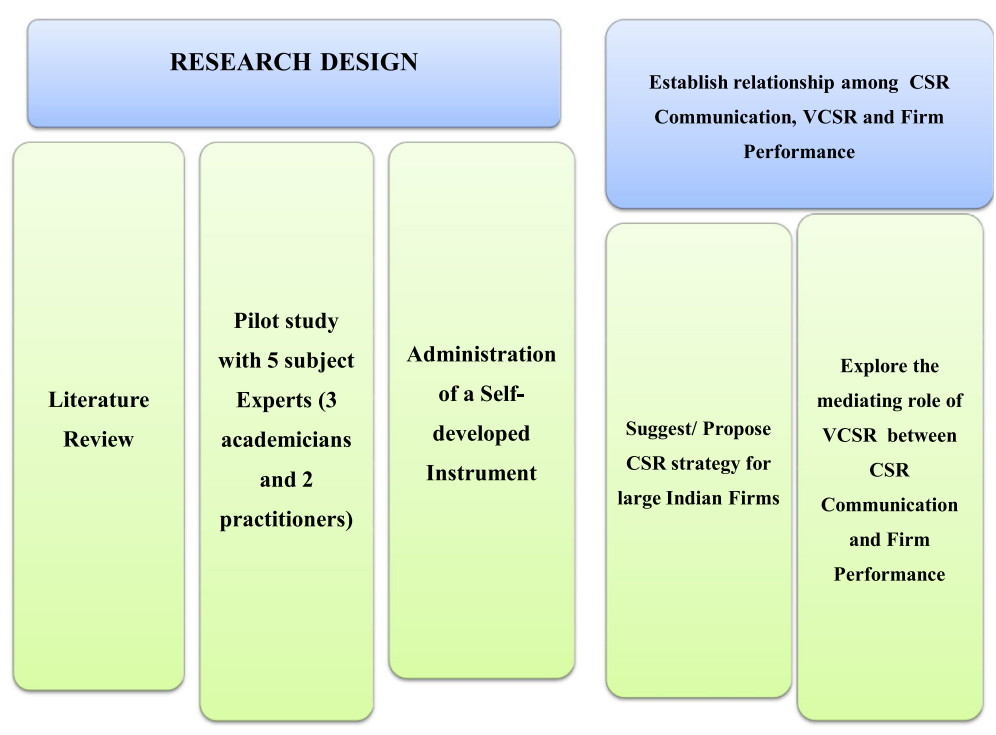

Fig. 2 Research Design, Source: Researchers' Contribution 
Table 4 Use of Databases in CSR Researches

\begin{tabular}{|c|c|}
\hline Database & CSR researchers \\
\hline $\begin{array}{l}\text { Prowess database of CMIE (Centre for Monitoring Indian Economy } \\
\text { Pvt. Ltd.) }\end{array}$ & Mishra and Suar 2010; Ghosh 2014. \\
\hline Karmayog CSR Rating & $\begin{array}{l}\text { Gautam and Singh 2010; Sharma and Kiran 2011; Guha 2011; Shanmugam } \\
\text { and Mohamed 2011; James 2012; Saxena and Kohli 2012; James 2013; Dutta } \\
\text { and Singh 2013; Ajith } 2014 .\end{array}$ \\
\hline BSE (Bombay Stock Exchange)/ NSE (National Stock Exchange) & $\begin{array}{l}\text { Rana and Misra 2010; Kansal and Singh 2012; Haldar and Mishra 2015; Chandra } \\
\text { and Kaur } 2015 .\end{array}$ \\
\hline
\end{tabular}

Source: Researchers' Compilation

usage of double barrelled items, ambiguous pronoun references and positive and negatively worded items (De Vellis 2003). Special emphasis was given to avoid confusing questions, gratuitous unconstructive questions, leading or loaded questions (Groves et al. 2004; Page and Meyer 2000; Whitley 2002; Khan 2014). Both formalized and unconcealed, and formalized and concealed questions were used.

A total of 24 items were shortlisted based on intensive review of previous literature, Isaksson's (2012) questionnaire and the judgement of 5 subject experts. The interval scale was used so that the respondent is able to answer the questions on a continuum scale. The questions were constructed on a 7 point Likert scale, mainly on an Agreement scale where 1 signifies 'Entirely Disagree' (ED) and 7 signifies 'Entirely Agree' (EA). Also, a few questions based on effectiveness scale, where 1 is 'Extremely Ineffective' and 7 is 'Extremely Effective' were used.

Response from Section 1 formed the sample description, used to describe the basic features of the data in the study and provide simple summaries about the sample and the measures; whereas Section "Literature review" provided the data for the inferential statistics of the research.

As literature review showed that Indian managers are generally averse to responding to questionnaire surveys, and statistically significant response rates are rare (Khan, 2008), the self-developed instrument (questionnaire) was sent to all 2500 Companies for self-administration with a covering letter assuring confidentiality of the usage of data. A self-administered questionnaire saves time, cost and manpower and, thus, it is advisable to use in case of a large sample.

\section{Planning and collecting the data for research}

Respondents included professionals who are a part of the CSR team of the Company. So, the respondents could be from various Departments, viz. Human Resource, Legal, Communication or Strategic Management in the Company, but should be a member of the CSR team of the Company. It was noticed that since structured CSR is a new phenomenon in India, initiated only after the passing of the CSR mandate, hence, even the largest of the Companies in India lacked a formal CSR department. This observation corroborates with Mishra and Suar's (2010) findings, which states: "Like a recent survey which finds that CSR activities of many Indian companies are mainly handled by public relations or human resources department rather than a CSR department (Sagar and Singla 2004), our survey also finds that $90 \%$ of the surveyed companies have neither an exclusive-department nor a specific budget for CSR."

Data was collected from April to November, 2016.

A web-enabled version of the master questionnaire was developed in googledocs and sent through e-mail with a covering letter to the 2500 companies, which had e-mail addresses. 93 emails returned immediately out of which 48 were 'mailer-daemon (unavailable email)' and 45 'not in office'. There was no response from the rest of the 2407 (2500-93) companies. The mail was sent again to the 2452 (2500-48) Companies after a lapse of fifteen days and again, 65 e-mails returned as 'not in office' and still no response from the 2387 (2452-65) Companies.

Baruch (1999) has identified two primary reasons for non-response, viz.

a) Failure to deliver the questionnaires to the intended population and

b) The reluctance of people to respond.

This was a genuine concern. While, it was confirmed that the questionnaire was reaching the intended population, then, the reason for this non-response was the reluctance of the respondents. Baruch and Holtom (2008) observed that such reluctance may occur due to reasons such as time constraint, topic irrelevance, or company policies to not participate in surveys (Krishnan and Poulose 2016).

A new strategy was then undertaken. The questionnaires were sent to the 2452 Companies again a third time and extensively followed-up one by one over phone on an ongoing basis. Contact was established and various other social media like text messages/ whatsapp/ email were used opulently to solicit response. This method of multiple survey mailings, incentives to 
respond and personal follow-ups have also been suggested by Cook et al. (2000); Krishnan and Poulose (2016). However, a principle was taken for non-incentivisation as it could lead to bias.

Thus, apart from the ongoing follow-ups, the following actions were also undertaken:

- Occasionally questionnaire was re-sent via googledoc link in email when necessary.

- Personal contact was made with 81 Companies, who preferred a one-on one interview rather than googledoc.

- Questionnaire was also sent as email attachments, who preferred a word/pdf document rather than googledoc.

And at last, over a period of seven months and continuous follow-ups, responses were received from 528 Companies (21.53\% response rate) out of 2452 questionnaires sent. The various reasons for not responding were multiple:

- Company going through a transition in its CSR domain due to compliance to the Companies Act, 2013,

- Unwillingness to share key financial data,

- Forbidden by Company policy,

- Some Companies fell under the same group Company, hence they were unwilling to share more than one response,

- Time constraint,

- Travel of key respondents.

Rejections to respond without stating any cause were plenty (938), thus affecting the response rate. It must be borne in mind that the response rate, in itself is not the sole criterion for assessing study quality, but one of the indicators to assess the potential contribution of a study (Campion 1993; Cook et al. 2000). The response rate information makes a useful reference when combined with the information on the efforts put in by the researcher to increase response rates and how the non-respondent bias has been tackled (Krishnan and Poulose 2016).

While googledoc only accepted filled-in questionnaires with complete responses, however, such filter was not possible when submitted through email attachments and physical copies. Raw data validation was done to ensure that all detectable errors and omissions have been examined and the necessary steps have been taken. So, even out of the 528 responses received, 216 were incomplete responses, where mostly, the respondents left some of the responses blank as a sensitive data. Complete response was collected from 312 Companies.
This result is somewhat unsurprising given that response rates to surveys have declined dramatically over time (Bradburn 1992; de Leeuw and Heer 2002; Dey 1997; Fraenkel and Wallen 1993; Smith 1995). As reported by Dey (1997), response rates to national mail out surveys have declined from approximately $60 \%$ to $21 \%$ since the 1960 s.

The outline of the process-flow of data collection has been provided below in Fig. 3:

Therefore, the empirical study was conducted among a sample size of 312 large companies, who fall within the CSR 2 \% mandate under the Companies Act, 2013.

\section{Data refining and preparation for analysis}

Post data collection, responses have been analysed to decipher conclusions and further recommendations. The tools that were employed to test the framed hypothesis are: Exploratory Factor Analysis (EFA), Confirmatory Factor Analysis (CFA) and Structural Equation Modelling (SEM). Mediation Analysis was done by using PROCESS (Hayes 2013). Two software packages viz. (Statistical Package for Social Sciences) SPSS 22, (Analysis of a moment structures) AMOS 21 were used for data analysis.

The Fig. 4 below gives a rough idea of the various stages of analysis undertaken in this research.

\section{Validity}

Importance has been given on the validity of the scale. Content validity, also called face validity has been done where the subjective judgement of five subject experts ( 3 academicians and 2 practitioners) have been considered to assess the appropriateness of the construct.

\section{Data analysis and discussion}

Once the rules of the research has been outlined in the Research Methodology, the scale is developed and tested for sample adequacy, after which the data is collected. This data is then analysed in order to provide a holistic comprehension of the sample description; the relationship of the various constructs or in other words, the testing of the hypothesis; and also, the mediator role of (Variable) Corporate Social Responsibility between CSR Communication and Firm Performance.

\section{Sample adequacy}

Sample adequacy is measured using Kaiser-Meyer-Olkin (KMO) test (Field 2005; Kaiser and Rice 1974). A bare minimum value of 0.5 is recommended by Kaiser et al. (1974). Therefore, a value of .774 indicates the suitability of the sample for conducting factor analysis.

Bartlett's Test of Sphericity (Bartlett 1954) also indicates the strength of the relationship among variables. It is used to test the null hypothesis that the original 


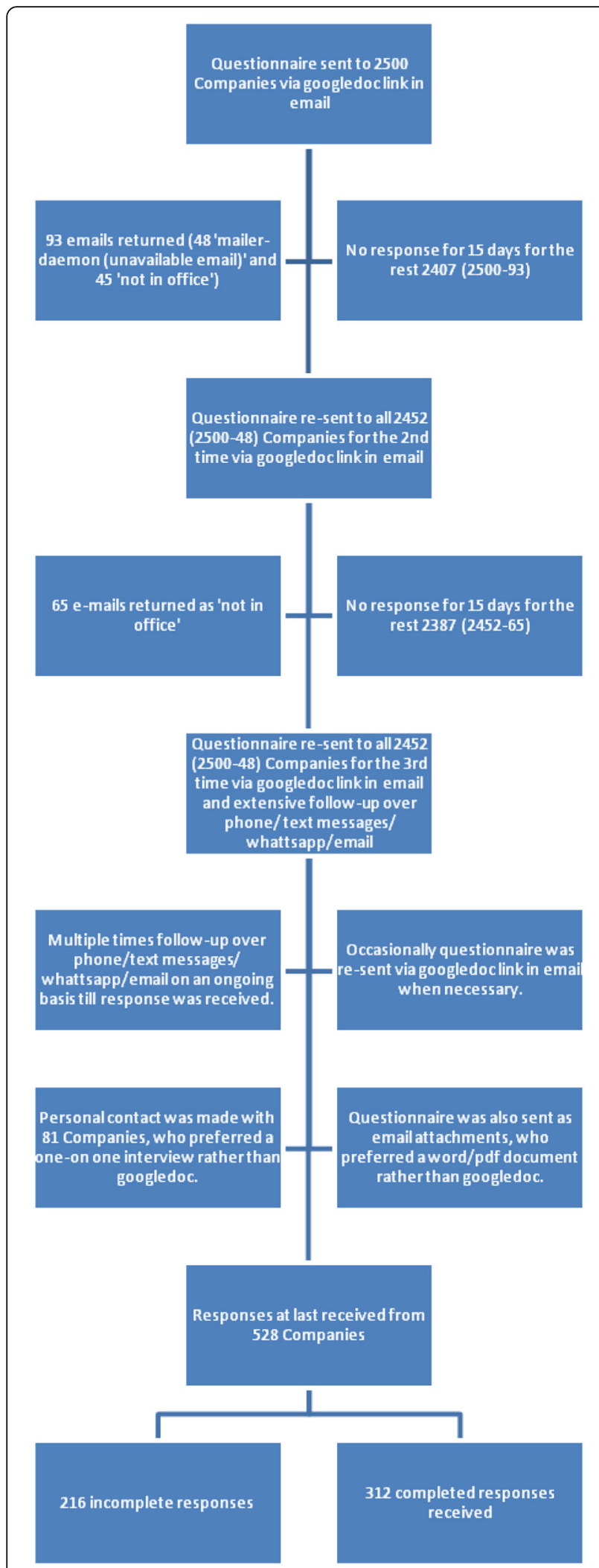

Fig. 3 The Process Flow of Data Collection, Source: Researchers' Contribution

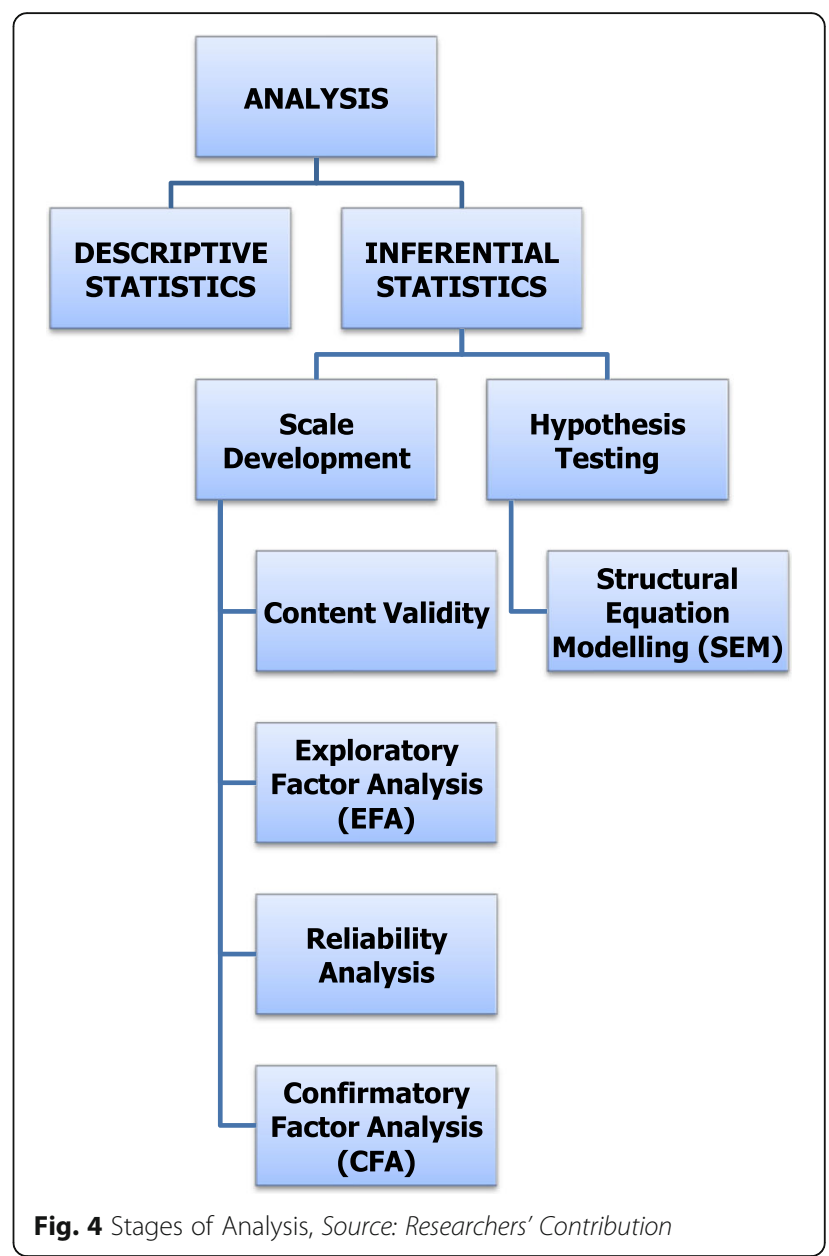

correlation matrix is an identity matrix indicating that the variables are unrelated in the population. A significant test will favour rejection of null hypothesis and indicate that there are some relationships among the variables, thus confirming the appropriateness of applying factor analysis. In the present study, Bartlett's test was significant $(p<0.01)$ indicating the fitness of the sample for factor analysis (Table 5).

\section{Exploratory factor analysis}

Factor analysis is a multivariate statistical procedure primarily used for data reduction and summarization. Exploratory Factor Analysis was used to condense the information contained in the original variables into a smaller set of variates (factors) with a minimum loss of information (Hair et al. 2010) so as to arrive at a more

Table $5 \mathrm{KMO}$ and Bartlett's Test

\begin{tabular}{lll}
\hline Kaiser-Meyer-Olkin Measure of Sampling Adequacy. & .774 \\
\hline Bartlett's Test of Sphericity & Approx. Chi-Square & 3898.871 \\
& Df & 276 \\
& Sig. & .000 \\
\hline
\end{tabular}


prudent conceptual understanding of the set of measured variables.

Here, both the Principal Component Analysis as well as Factor Analysis has been used to determine the type of extraction. Factor analysis is often used in data reduction to identify a small number of factors that explain most of the variance observed in a much larger number of manifest variables. It attempts to identify underlying variables, or factors, that explain the pattern of correlations within a set of observed variables. Factor analysis can also be used to generate hypotheses regarding causal mechanisms or to screen variables for subsequent analysis (for example, to identify co-linearity prior to performing a linear regression analysis).

Factor extraction Total Variance Explained (Table 6) lists the eigenvalues associated with each linear component (factor) before extraction, after extraction and after rotation. Before extraction, SPSS has identified 24 linear components within the data set (we know that there should be as many eigenvectors as there are variables and so there will be as many factors as variables). The eigenvalues associated with each factor represent the variance explained by that particular linear component and SPSS also displays the eigenvalue in terms of the percentage of variance explained (here, factor 1 explains $25.727 \%$ of total variance). Infact, $70.932 \%$ of total variance has been explained by only 7 factors, whereas subsequent factors explain only small amounts of variance. The eigenvalues associated with these factors are again displayed (and the percentage of variance explained) in the columns labelled Extraction Sums of Squared Loadings. The values in this part of the table are the same as the values before extraction, except that the values for the discarded factors are ignored (hence, the table is blank after the seventh factor).

In the final part of Table 6 (labelled Rotation Sums of Squared Loadings), the eigenvalues of the factors after rotation are displayed. Rotation has the effect of optimizing the factor structure and one consequence for these data is that the relative importance of the seven factors is equalized. Before rotation, factor 1 accounted

Table 6 Total Variance Explained

\begin{tabular}{lll}
\hline Component & \% of Variance & Cumulative \% \\
\hline 1 & 14.160 & 14.160 \\
2 & 14.098 & 28.258 \\
3 & 11.994 & 40.252 \\
4 & 9.303 & 49.555 \\
5 & 8.460 & 58.015 \\
6 & 8.002 & 66.017 \\
7 & 4.914 & 70.932 \\
\hline
\end{tabular}

Extraction Method: Principal Component Analysis for considerably more variance than the remaining six (25.727\%), however, after extraction, it accounts only for $14.160 \%$ of variance.

Table 7 shows the Communalities before and after extraction. Principal component analysis works on the initial assumption that all variance is common; therefore, before extraction the communalities are all 1.000. The communalities in the column labelled 'Extraction' reflect the common variance in the data structure. So, we can say, that $80.3 \%$ of the variance associated with Question 1 (S30) is common or shared variance.

The Component matrix (Table 8) contains the factor loadings of each variable onto each factor. By default, SPSS displays all loadings, however, we requested that all loadings less than 0.4 should be suppressed in the output. But, all 24 items had loadings greater than 0.4 as is evident from Table 8.

\section{Confirmatory factor analysis Identification of model}

As shown below, the estimation of the hypothesized model resulted in an overall chi-square value of 266.196 with 105 (153-48) degrees of freedom and the probability value of .000 . Of importance also is the notation that the minimum was achieved. This indicates that the software (AMOS) ran successfully in estimating all the parameters, thereby resulting in convergent solution (Byrne 2009).

Notes for Model (Default model).

Computation of degrees of freedom (Default model).

Number of distinct sample moments:

Number of distinct parameters to be estimated:

48

Degrees of freedom (153-48):

Table 7 Communalities

\begin{tabular}{llllll}
\hline Items & Initial & Extraction & Items & Initial & Extraction \\
\hline S30VCOM & 1.000 & .803 & S61VCSR & 1.000 & .605 \\
S31VCOM & 1.000 & .716 & S62VCSR & 1.000 & .548 \\
S32VCOM & 1.000 & .504 & S63VCSR & 1.000 & .734 \\
S33VCOM & 1.000 & .716 & S64VCSR & 1.000 & .554 \\
S34VCOM & 1.000 & .784 & S65VFP & 1.000 & .705 \\
S35VCOM & 1.000 & .718 & S66VFP & 1.000 & .813 \\
S36VCOM & 1.000 & .592 & S69VFP & 1.000 & .742 \\
S56VCSR & 1.000 & .829 & S70VFP & 1.000 & .785 \\
S57VCSR & 1.000 & .763 & S71VFP & 1.000 & .677 \\
S58VCSR & 1.000 & .769 & S72VFP & 1.000 & .821 \\
S59VCSR & 1.000 & .688 & S73VFP & 1.000 & .703 \\
S60VCSR & 1.000 & .743 & S77VFP & 1.000 & .709 \\
\hline Extaction
\end{tabular}

Extraction Method: Principal Component Analysis 
Table 8 Factor Loadings of the Items

\begin{tabular}{llll}
\hline Items & Loadings & Items & Loadings \\
\hline S30VCOM & .817 & S61VCSR & .650 \\
S31VCOM & .676 & S62VCSR & .695 \\
S32VCOM & .604 & S63VCSR & .568 \\
S33VCOM & .745 & S64VCSR & .601 \\
S34VCOM & .542 & S65VFP & .591 \\
S35VCOM & .761 & S66VFP & .840 \\
S36VCOM & .715 & S69VFP & .694 \\
S56VCSR & .812 & S70VFP & .667 \\
S57VCSR & .738 & S71VFP & .733 \\
S58VCSR & .551 & S72VFP & .792 \\
S59VCSR & .814 & S73VFP & .755 \\
S60VCSR & .754 & S77VFP & .786 \\
\hline
\end{tabular}

Chi-square $=1588.468$

Degrees of freedom $=249$

Probability Level $=.000$

Among the various techniques used for running CFA, the present study adopts the Maximum Likelihood Estimation (MLE) (Scholz 1985). MLE method is suitable for the continuous data. Before running the MLE method, the data was required to be measured on normality indices.

\section{Fit-indices (Table 9)}

Apart from chi-square goodness-of-fit test, there are various ancillary indices of fit i.e. goodness of fit index and adjusted goodness-of-fit index (GFI, AGFI Joreskog and Sorbom 1986), the comparative fit index (CFI, Bentler 1990), and root mean square error of approximation (RMSEA, Steiger and Lind 1980). The GFI is the measure of relative amount of variance and covariance in sample data that is jointly explained by sigma. The AGFI is quite different from the GFI only in the case where it adjusts the number of degrees of freedom in the specified model. The value of these indices ranges from zero to 1.00 , being value close to one is indication of good fit. In Table 9, The values of the GFI and AGFI are found to be .915 and .877 respectively and GFI is conforming to the recommended value. The CFI (Bentler 1990) assesses fit relative to other models and uses an approach based on the non-central $x^{2}$ distribution with non-centrality

Table 9 Fit Indices

\begin{tabular}{lll}
\hline Fit-indices & Recommended & Observed \\
\hline CMIN/DF & $<3$ & 2.535 \\
GFI & $>.9$ & .915 \\
AGFI & $>.9$ & .877 \\
RMSEA & $<.08$ & .070 \\
CFI & $>.9$ & .936 \\
\hline
\end{tabular}

parameter. CFI values greater than .9 are often indicative of good fitting models ( $\mathrm{Hu}$ and Bentler 1999). For our analysis, CFI stands with .936. The RMSEA takes into account the error of approximation in the population and asks the question "How well would the model, with unknown but optimally chosen parameter values, fit the population covariance matrix if it were available?" (Browne and Cudeck 1993). The RMSEA is found to be .070 .

\section{Reliability analysis}

Reliability analysis is done to check the consistency of the ratings produced by the scale (Malhotra 2007; Warner 2008). The reliability of the scale is high in case the value of the Cronbach's alpha is greater than .60 . Present study found the value of the Cronbach's alpha .860 which is significant with 24 items in the scale. We have also checked the reliability analysis of the factors separately which is given in the following Table 10.

Having developed the scale of the research, and post its verification for validity and reliability, the research instrument was finalised, data was collected and analysed with the help of various statistical instruments.

\section{Sample description}

Descriptive Statistics (Table 11) reveals that out of the 312 companies, 50\% belonged to the Manufacturing sector, followed by the service sector (39.4\%) and last, but not the least with the Mining sector (10.6\%). The majority of the sample were from the Private sector (71.2\%), out of which $72.1 \%$ were of Indian origin. The respondents were mainly Top Level Managers (65.4\%) in the organisational hierarchy; had work experience of 21 and above years (49\%) and belonged to the age-group of 40-60 years (66.3\%) and were highly qualified with $65.4 \%$ having post graduate education.

Descriptive statistics further divulges that while 30.8\% belonged to the Top Management Team (Managing Director/ Chief Executive Officer/ Board Member/ Director), the rest $69.2 \%$ belonged to the various functional departments like the CSR department (29.8\%), Human Resource department (12.5\%), Company Secretary (5.8\%), Public Relations (2.9\%) and others (18.3\%) of the Company. Thus, the observation was that the CSR team members often belonged to various departments. This is because, since structured

Table 10 Reliability Analysis

\begin{tabular}{lll}
\hline Factors & No. of items & a-value \\
\hline Communication & 7 & 0.758 \\
(Variable) Corporate Social Responsibility & 9 & 0.837 \\
Firm Performance & 8 & 0.833 \\
Overall & 24 & 0.860 \\
\hline
\end{tabular}


Table 11 Sampling Profile of Respondents

\begin{tabular}{|c|c|c|}
\hline & Frequency & Percent \\
\hline \multicolumn{3}{|l|}{ Age } \\
\hline Below 39 yrs & 87 & 27.9 \\
\hline $40-60$ yrs & 207 & 66.3 \\
\hline 61 yrs. and above & 18 & 5.8 \\
\hline Total & 312 & 100.0 \\
\hline \multicolumn{3}{|l|}{ Gender } \\
\hline Male & 267 & 85.6 \\
\hline Female & 45 & 14.4 \\
\hline Total & 312 & 100.0 \\
\hline \multicolumn{3}{|l|}{ Education } \\
\hline Graduate & 57 & 18.3 \\
\hline Post Graduate & 204 & 65.4 \\
\hline Others & 51 & 16.3 \\
\hline Total & 312 & 100.0 \\
\hline \multicolumn{3}{|l|}{ Work Experience } \\
\hline 10 yrs. and below & 42 & 13.5 \\
\hline $11-20 \mathrm{yrs}$ & 117 & 37.5 \\
\hline 21 yrs. \& above & 153 & 49.0 \\
\hline Total & 312 & 100.0 \\
\hline \multicolumn{3}{|l|}{ Management } \\
\hline Frontline Manager & 24 & 7.7 \\
\hline Middle-level Manager & 84 & 26.9 \\
\hline Top-level Manager & 204 & 65.4 \\
\hline Total & 312 & 100.0 \\
\hline \multicolumn{3}{|l|}{ Position } \\
\hline CSR & 93 & 29.8 \\
\hline$H R$ & 39 & 12.5 \\
\hline Top Management & 96 & 30.8 \\
\hline Company Secretary & 18 & 5.8 \\
\hline Public Relations & 9 & 2.9 \\
\hline Others & 57 & 18.3 \\
\hline Total & 312 & 100.0 \\
\hline \multicolumn{3}{|l|}{ Nature of Company } \\
\hline Private & 222 & 71.2 \\
\hline Public & 90 & 28.8 \\
\hline Total & 312 & 100.0 \\
\hline \multicolumn{3}{|l|}{ Private Sector } \\
\hline Indian Origin & 225 & 72.1 \\
\hline Foreign Origin & 84 & 26.9 \\
\hline Others & 3 & 1.0 \\
\hline Total & 312 & 100.0 \\
\hline \multicolumn{3}{|l|}{ Type of Industry } \\
\hline Service & 123 & 39.4 \\
\hline Manufacturing & 156 & 50.0 \\
\hline Mining & 33 & 10.6 \\
\hline Total & 312 & 100.0 \\
\hline
\end{tabular}

CSR is a new phenomenon in India, initiated only after the passing of the CSR mandate, hence, even the largest of the Companies in India lacked a formal CSR department.

Table 11 exposes that this research has only $14.4 \%$ female respondents as compared to $85.6 \%$ male respondents. This does not come as a surprise as even the Mukesh Ambani led Reliance Industries Limited, largest private sector company and the first Indian company featured in Fortune Global 500 list, aspires to achieve only $15 \%$ women workforce by 2030 , as revealed in their latest Annual Report (India CSR 2017). Infact, India has the lowest percentage of women employees (23\%), followed by Japan (24\%), Turkey (26\%) and Austria (29\%), according to the Corporate Gender Gap report brought out by the World Economic Forum (CSR Vision 2017). Hence, such discriminatory response of women respondents.

\section{Impact of CSR communication on (variable) CSR and that of (variable) CSR on firm performance}

The analysis of the structural equation modelling (SEM) specifies the relationship among latent variables as specified by the theory. SEM is also referred to as causal modelling, causal analysis, simultaneous equation modelling, and analysis of covariance structures, path analysis, or CFA (Ullman 2006).

The model of CSR communication with (Variable) CSR and company performance appears in Fig. 5. In this model, there are three latent variables among which two are independent namely (Variable) CSR and Communication, and one variable is dependent i.e. Firm Performance. Furthermore the (Variable) CSR here is used as a mediating variable between Communication and firm performance. These variables are not directly measured but rather assessed indirectly by seven items in communication and nine items in (Variable) CSR, while the dependent variable is measured by eight items in the construct. The observed variables, signified by rectangles, are measured on a seven point likert scale. The latent variables are calculated by taking the average of the observed variables. The present study has been tested through various models and the one, which has higher values of the fit indices has been adopted. This model comprises of company performance as a dependent variable, while (Variable) CSR and communication are independent variables.

Model (Default model).

Computation of degrees of freedom (Default model).

Number of distinct sample moments:

Number of distinct parameters to be estimated: 


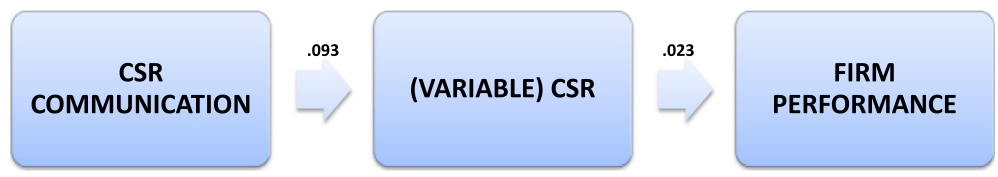

Fig. 5 The Research Model, Source: Researchers' Own

The fit indices of the structural equation modelling is given in Table 12. The analysis starts with the evaluation of the fit indices. Overall, the values of the fit indices are not what has been recommended but still they are at the satisfactory level. The value of the CMIN/DF is 2.518, which is quite higher than 2 as is the threshold value suggested by Ullman, 2001 and is less than 5. The RMSEA value for the structural model is .07 which is less than .08 (Browne and Cudeck 1993; (Hu \& Bentler, 1998). Other fit indices were $\mathrm{GFI}=.915, \mathrm{AGFI}=.878$, and CFI $=.936$. All the fit indices except AGFI are found satisfactory.

\section{Results and discussions based on SEM}

Based on the Structural Equation Model, the impact of CSR Communication on (Variable) CSR and the impact of (Variable) CSR on Firm Performance can be analysed. This can be understood with the help of the Fig. 5 below and has been further illustrated in Table 13. The impact has further been discussed in detail thereafter.

Impact of csr communication on (variable) corporate social responsibility It was observed that CSR Communication has both a positive and statistically significant $(P=<0.05)$ impact on (Variable) Corporate Social Responsibility $(\mathrm{S} . \mathrm{E}=.093)$. Therefore, hypothesis $\mathrm{H}_{1.4}$ is supported.

This finding corroborates with Ligeti and Oravecz (2009), who states that "Corporate Social Responsibility and the related communication are inseparable." Information about CSR helps consumers to learn about the company's value system (Lee et al. 2009; Sen and Bhattacharya 2001) and to acquire consumers' positive perception about a particular company (Menon and Kahn 2003; Yoon et al. 2006). However, consumers look closely at companies that make claims regarding their

Table 12 SEM Fit-Indices

\begin{tabular}{lll}
\hline Fit-indices & Recommended & Observed \\
\hline CMIN/DF & $<3$ & 2.518 \\
GFI & $>.9$ & .915 \\
AGFI & $>.9$ & .878 \\
RMSEA & $<.08$ & .070 \\
CFI & $>.9$ & .936 \\
\hline
\end{tabular}

Chi-square $=1590.650$

Degrees of freedom $=250$

Probability level $=.000$ involvement on social issues (Bronn and Vrioni 2001). Hence, CSR communication should be factual and avoid the impression of boasting with it (Sen et al. 2009). Kuhn and Deetz (2008) contend that CSR should be "motivated by enriched processes of communication that engender authentic stakeholder participation, incorporate various social values, and operate within a process that constructively engages in conflict to inspire creative solutions."

Impact of (variable) corporate social responsibility on firm performance The result of Structural Equation Model reveals that (Variable) Corporate Social Responsibility has both a positive $(\mathrm{S} . \mathrm{E}=.023)$ and a statistically significant $(P=<0.05)$ impact on Firm Performance. Therefore, hypothesis $\mathrm{H}_{3}$ is supported.

This confirms to Rettab et al.'s (2009) investigation that notes that CSR has a positive relationship with Corporate reputation even in emerging economies where the researchers expect that CSR activities will not be communicated effectively to external stakeholders due to lack of skills and effective channels. Superti (2005) also lists 'enhanced brand image and reputation' as key non-financial firm performance that is impacted from CSR. Peloza and Papania (2008), however suggests that in attempting to improve and sustain its own reputation, the firm must manage its own CSR activities while keeping an eye on the actions of other firms within its industry; the actions of its industry associations; and even developments in other industries that may shift the playing field.

\section{Mediator analysis}

In order to analyze the mediating role of (Variable) Corporate Social Responsibility (VCSR) as a mediator between CSR Communication and Firm Performance (VFP), the PROCESS program developed by Hayes (2013) was used.

The hypothesis derived for this are as follows:

$H_{3}$ : (Variable) Corporate Social Responsibility (VCSR) mediates the relationship between CSR Communication and Firm Performance.

Simple mediation framework (Model 4) of the PROCESS programme was used to get the results of mediation. If the range of Lower Control Limit (LCL) and Upper Control Limit (UCL) for indirect effect contains zero values, it signifies no mediation; but if the 
Table 13 Results of SEM in Tabular Form

\begin{tabular}{lllllll}
\hline Independent Variable & Dependent Variable & Hypothesis & (S.E) & Construct Reliability (C.R) & (P) & Result \\
\hline VCOM & VCSR & $H_{01}$ & .093 & 4.366 & *** & Positive and Significant \\
VCSR & VFP & $H_{02}$ & .023 & 2.968 & .003 & Positive and Significant \\
\hline
\end{tabular}

range of LCL and UCL for indirect effect contains no zero values, it signifies mediation role. The findings are discussed in Table 14.

It is found from the Table 14 above that (Variable) Corporate Social Responsibility does have a mediating effect between CSR Communication and Firm Performance.

\section{Conclusion}

The contribution of this research can be drawn both in terms of its theoretical as well as managerial implications, as hereunder:

From the theoretical point of view, the empirical results of this research support some previously made and analyzed assumptions while questioning some of the others. Some of the major theoretical findings of this empirical research among the large Indian Firms in the post mandate period are as follows:

- CSR Communication has a positive as well as a significant relationship with (Variable) Corporate Social Responsibility;

- (Variable) Corporate Social Responsibility has both a positive and significant relationship with Firm Performance.

Needless to say, while some of the extant theories had already established the above-mentioned significance among the relations, it was mostly done in a different contextual setting.

Mandated CSR is a new area of study as one of the pioneers of CSR mandate, is India itself, having brought CSR under its statute only in the year 2013. The findings of this research thus forms some of the early theoretical bases for study in mandated CSR in an emerging country like that of India. Incidentally, the CSR mandate is also applicable to the large Indian firms, which has the same sampling frame as that of this research.

On the other hand, any management research is incomplete without indicating its practical, managerial implications. This research contributes to this by

Table 14 (Variable) Corporate Social Responsibility as a Mediator Between CSR Communication and Firm Performance

\begin{tabular}{llllll}
\hline $\mathrm{H}$ & MEDIATOR & RELATIONSHIP & \multicolumn{2}{c}{ INDIRECT EFFECT } & ROLE \\
\cline { 3 - 4 } & & LCL & UCL & \\
\hline $\mathrm{H}_{3}$ & VCSR & VCOM-VCSR-VFP & .0257 & .0978 & Mediation \\
\hline
\end{tabular}

pointing out that (Variable) Corporate Social Responsibility has a mediating effect between CSR Communication and Firm Performance. Thus, it can be deduced that (Variable) Corporate Social Responsibility can be used strategically to induce better firm performance by utilising CSR communication efficiently and effectively. In other words, management must start looking at (Variable) Corporate Social Responsibility not as an expenditure but as an investment as it induces better firm performance. Infact, this itself is the most important (Variable) Corporate Social Responsibility strategy for large Indian firms in the context of their firm performance.

\section{Limitations and future research directions}

However, like all researches, this empirical study is also not without limitations and way forward, that has been enumerated below:

\section{Limitations}

The limitations of this research are many. Some of them are as follows:

- It is conducted only in the context of one country, India and hence, limited by its socio-economicdemographic background.

- The research is conducted among the large Indian firms, and hence, does not consider the vibrant dynamics of the Micro, Small and Medium Enterprise (MSME) sector that forms the backbone of the Indian economy.

- Quantitative techniques has been mainly used, that has been supported by qualitative data. Hence, although the data collection was practical and could be analyzed more scientifically and objectively than other forms, it has its inherent drawbacks. For example, there is always a threat of biased sample due to non-response and misinterpretation of a question among others.

- In the absence of a CSR index in India, the parameters in Schedule VII of the Companies Act, 2013 were used. A CSR Index would have been more holistic and measureable in terms of research findings.

- The research is based on the opinions and perceptions of the respondent belonging to the CSR team of the Company. Hence, the responses 
are limited to his/her perceptions alone and not of other executives in the Company.

Keeping the above mentioned limitations in view, the research findings cannot be generalised in any other context.

\section{Future research directions}

The possible future research directions are as follows:

- This present research is limited only to India and can be further tested in other countries.

- Moreover, a completely independent research can be undertaken with the same constructs, but catering to the MSME sector in India. These MSMEs play a vital role for the growth of Indian economy. The annual report of MSME 2012-13, has confirmed that the 44.7 million MSME enterprise with a total employment of over 100 million and more than 6000 quality products account for a large share of industrial units; as well as 43\% of India's total exports in 2011-12 (Ministry of Finance; 2013).

- This research with the same constructs can be re-administered few years hence when the CSR Index is formed in India. The BSE Ltd and the IICA are currently working on the preparation of the CSR Index for India.

- Moreover, it may be interesting to note the perceptions and opinions of respondents who do not belong to the CSR team in these large Indian Companies. Their responses, may vary completely from the research findings of this present investigation.

\section{Appendix 1}

\section{Section 135 of the companies act, 2013}

Every company having a net worth of INR 5 billion or more, or a turnover of INR 10 billion or more, or a net profit of INR 50 million or more during any financial year shall constitute a Corporate Social Responsibility Committee of the Board consisting of three or more directors, out of which at least one director shall be an independent director;

The Board's report shall disclose the composition of the CSR Committee.

The Corporate Social Responsibility Committee shall: formulate and recommend to the Board, a CSR Policy which shall indicate the activities to be undertaken by the company as specified in Schedule VII recommend the amount of expenditure to be incurred on these CSR activities monitor the CSR policy of the Company from time to time.

The Board of these Companies that shall:
After taking in account the recommendations made by the CSR Committee, approve the CSR policy for the Company and disclose the contents of such Policy in its report and also place it on the company's website, if any, in such manner as may be prescribed; and Ensure that the activities are included in their CSR Policy and are actually undertaken by the company.

The Board of these companies, shall ensure that the company spends, in every financial year, at least $2 \%$ of the average net profits of the Company made during the three immediately preceding financial years, in pursuance of its CSR policy.

Moreover, the Section 135 also provides a direction to these Companies to give preference to the local area and areas around it where it operates, for spending the amount earmarked for CSR activities.

However, the law also states that if the company fails to spend such amount, the Board shall, in its report, specify the reasons for not spending the amount.

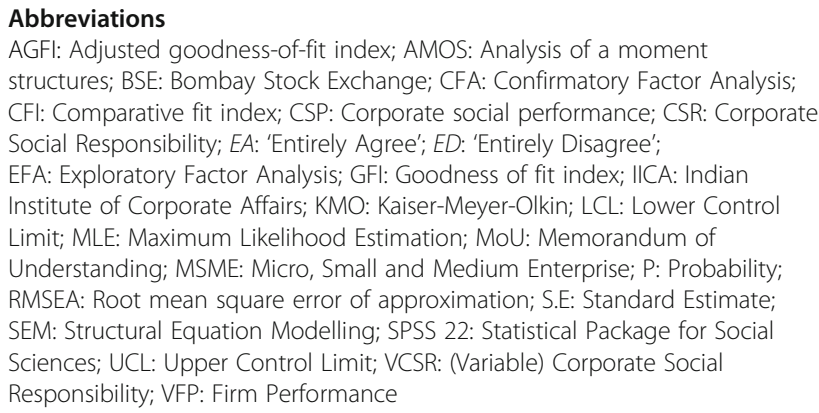

Acknowledgements

We are thankful to our reviewers at the International Journal of CSR for their valuable inputs. We have incorporated all their suggestions that has made the research more robust.

\section{Funding}

We are grateful and acknowledge the contribution of Cologne Business School to undertake the Article Processing Charge (APC) for this paper, post double blinded peer review.

Availability of data and materials

The datasets supporting the conclusions of this article are included within the article and its supporting documents.

Authors' contributions

All the authors equally and substantially contributed to the conception, drafting and revising of the work. While Dr. NM has formulated the research objectives, hypotheses and collected the data, Dr. AA has run the statistical analysis, as part of the research methodology. Dr. ADG has provided the overall review. All authors read and approved the final manuscript.

Competing interests

The authors declare that they have no competing interests.

\section{Publisher's Note}

Springer Nature remains neutral with regard to jurisdictional claims in published maps and institutional affiliations. 


\section{Author details}

${ }^{1}$ Independent Developmental Consultant, Kolkata, India. ${ }^{2}$ Aligarh Muslim University, Aligarh, India. ${ }^{3}$ Indian Institute of Plantation Management, Bangalore, India.

\section{Received: 5 October 2017 Accepted: 13 June 2018}

Published online: 27 June 2018

\section{References}

Abdel-Maksoud, A., Dugdale, D., \& Luther, R. (2005). Non-financial performance measurement in manufacturing companies. British Accounting Review, 37(3), 261-297.

Ajith, K. N. (2014). Corporate Organizations: Community Relations. SCMS Journal of Indian Management January-March.

Bartlett, M. S. (1954). A note on the multiplying factors for various $x 2$ approximations. Journal of the Royal Statistical Society. Series $B$ (Methodological), 296-298.

Baruch, Y. (1999). Response rate in academic studies - a comparative analysis. Human relations, 52, 421-438.

Baruch, Y., \& Holtom, B. C. (2008). Survey response rate levels and trends in organizational research. Human Relations, 61, 1139-1160

Beatty, R. P., \& Ritter, J. R. (1986). Investment banking, reputation and underpricing of initial public offerings. Journal of Financial Economics, 15, 213-232.

Beena, P. L. (2014). Mergers and acquisitions: India under globalisation. New Delhi: Routledge.

Bentler, P. M. (1990). Comparative fit indexes in structural models. Psychological Bulletin, 107(2), 238-246

Bradburn, N. M. (1992). Presidential address: A response to the non-response problem. Public Opine, 56, 391-398.

Bromwich, M., \& Bhimani, A. (1994). Management Accounting: Pathways to Progress. London: Chartered Institute of Management Accountants.

Bronn, P. S., \& Vrioni, A. B. (2001). Corporate social responsibility and cause related marketing: An overview. International Journal of Advertising, 20(2), 207-222.

Browne, M. W., \& Cudeck, R. (1993). Alternative ways of assessing model fit. In K. A. Bollen \& J. S. Long (Eds.), Testing structural equation models (pp. 136-162) Beverly Hills: Sage.

BSE India. (2015). BSE and Sustainability. http://www.bseindia.com/static/about/ sustainability.aspx? expandable=4. Accessed 3 Jan 2015.

Byrne, B. M. (2009). Structural equation modeling with AMOS: Basic concepts, applications, and programming (2nd ed.). New York, NY: Taylor \& Francis.

Campion, M. A. (1993). A criterion checklist for reviewing research articles in applied psychology. Personnel Psychology, 705-718.

Carroll, A. B. (2008). A History of Corporate Social Responsibility: Concepts and Practices. https://www.researchgate.net/publication/282746355_A_History_of_Corporate_ Social_Responsibility_Concepts_and_Practices. Accessed 4 Nov 2017.

Chandra, R., \& Kaur, P. (2015). Corporate social responsibility spend by corporate India and its composition. IUP Journal of Corporate Governance, 68-79.

Chapple, W., \& Moon, J. (2005). Corporate social responsibility (CSR) in Asia: A Seven Country Study of CSR Website Reporting. Business and Society, 44(4), 415-441.

Chatterjee, B., \& Mitra, N. (2017). CSR should contribute to the national agenda in emerging economies - the 'Chatterjee model'. International Journal of Corporate Social Responsibility. https://doi.org/10.1186/s40991-017-0012-1.

Chawla, D., \& Sondhi, N. (2011). Research Methodology: Concepts and Cases (Ist ed. ). Noida, New Delhi: Vikas Publishing House Pvt Ltd.

Conceptual framework. (n.d.). In Business Dictionary. http://www.businessdictionary. com/definition/conceptual-framework.html. Accessed 23 Oct 2017.

Cook, C., Heath, F., \& Thompson, R. L. (2000). A meta-analysis of response rates in web-or internet-based surveys. Educational and Psychological Measurement, 60(6), 821-836

CSR Vision. (2017). Women Empowerment and CSR. http://www.csrvision.in/ women-empowerment-and-csr/. Accessed on 4 October 2017

Das Gupta, A. (2012). Corporate social responsibility and strategy: A Bird's eye view. (article). Global Business Review, 13(1), 153-165.

Deephouse, D. L., \& Ourso, E. J. (1997). The effect of financial and media reputations on performance. Corporate Reputation Review, $1(1 \& 2)$ https://www.ualberta.ca/business/daviddeephouse/Research/ /media/ business/FacultyAndStaff/SMO/DavidDeephouse/Documents/ DeephouseCrr1997EffectOfFinancialAndMediaReputations.ashx. Accessed 23 Feb 2015. de Leeuw, E., \& Heer, W. (2002). Trends in household survey nonresponse: A longitudinal and international comparison. In R. M. Groves, D. A. Dillman, J. L. Eltinge, \& R. J. A. Little (Eds.), Survey nonresponse (pp. 41-54). New York: Wiley. De Vellis, R. F. (2003). Scale development: Theory and applications. Sage Publication.

Dey, E. L. (1997). Working with low survey response rates: The efficacy of weighing adjustments. Research in Higher Education Journal, 38, 215-227.

Dutta, K., \& Singh, S. (2013). Customer perception of CSR and its impact on retailer evaluation and purchase intention in India. Journal of Services Research, 13(1)

Eberhard-Harribey, L. (2006). Corporate social responsibility as a new paradigm in the European policy: How CSR comes to legitimate the European regulation process. Corporate Governance, 6(4), 358-368.

Epstein, M. J., \& Roy, M. J. (2001). Sustainability in action: Identifying and measuring the key performance drivers. Long Range Planning, 34(5), 585-604

Erden, D., \& Bodur, M. (2013). Responsibility and Performance: Social Actions of firms in a Transitional Society. In G. Aras \& D. Crowther (Eds.), A Handbook of Corporate Governance and social responsibility (pp. 341-364). Surrey: Gower Publishing Limited.

Field, A. (2005). Factor analysis using SPSS. http://users.sussex.ac.uk/ andyf/factor.pdf. Accessed July 102014

Fombrun, C. J. (1996). Reputation: Realizing Value from the Corporate Image. Boston: Harvard Business School Press.

Fraedrich, J., \& Ferrell, O. (2008). Ethical Decision Making for Business. SouthWestern: Cengage Learning.

Fraenkel, J. R., \& Wallen, N. E. (1993). How to design and evaluate research in education (2nd ed.). New York: McGraw Hill.

Frederick, W. C. (2006). Corporation be good: The story of corporate social responsibility. Indianapolis: Dog Ear Publishing.

Friday, O. B. (2015). The role of corporate social responsibility and its relevance in the Nigerian oil industry. The International Journal Of Business \& Management.

Gautam, R., \& Singh, A. (2010). Corporate social responsibility practices in India: A study of top 500 companies. Global Business and Management Research - An International Journal, 2(1), 41-56 http://www.gbmr.ioksp.com/pdf/ Gautam\%20\&\%20Singh,\%202010.pdf. Accessed 5 Aug 2013.

Ghosh, S. (2014). A study of the participation of the private sector companies of India in corporate social responsibility activities through conjoint analysis. (article). Vision, 18(2), 91-108.

Gray, R. H., Owen, D. L., \& Adams, C. (1996). Accounting and accountability, changes and challenges in corporate social and environmental reporting. Hemel Hempstead: Prentice Hall.

Groves, R., Fowler, F., Couper, M., Lepkowski, J., Singer, E., \& Tourangeau, R. (2004). Survey Design. Hoboken: Wiley.

Guha, L. (2011). Corporate social responsibility rating: India focus. The IUP Journal of Management Research, X(3), 28-41.

Habisch, A., Jonker, J., \& Wegner, M. (2005). Corporate Social Responsibility across Europe. In A. Habisch, J. Jonker, \& M. Wegner (Eds.), Corporate social responsibility across Europe. Berlin: Springer-Verlag.

Hair, J. F., Black, W., Babin, B., \& Anderson, R. (2010). Multivariate data analysis (7th ed.)

Haldar, P. K. \& Mishra, L. (2015). The changing facets of corporate governance and corporate social responsibilities in India and their interrelationship. Information Management and Business Review, 7(3), 6-16.

Hall, R. (1992). The strategic analysis of intangible resources. Strategic Management Journal, 13, 135-144.

Hayes, A. F. (2013). Introduction to mediation, moderation, and conditional process analysis: A regression-based approach. New York: Guilford Press.

Heal, G. (2005). Corporate social responsibility: An economic and financial framework The Geneva Papers on Risk and Insurance - Issues and Practice, 30(3), 387-409.

$\mathrm{Hu}$, L. T., \& Bentler, P. M. (1999). Cutoff criteria for fit indexes in covariance structure analysis: Conventional criteria versus new alternatives. Structural equation modeling: a multidisciplinary journal, 6(1), 1-55.

India CSR. (2017). Reliance aspires to achieve 15\% women workforce by 2030. http://indiacsr. in/reliance-aspires-to-achieve-15-women-workforce-by-2030/. Accessed 4 Oct 2017.

Isaksson, L. (2012). Corporate Social Responsibility: A study of Strategic Management and Performance in Swedish Firms. Dissertation approved for the Bond University School of Business. Gold Coast, Australia.

Ittner, C. D., \& Larcker, D. F. (2003). Coming up short on nonfinancial performance measurement. Harvard Business Review, 81, 88-95.

James, L. (2012). Prospects of CSR: An overview of 500 Indian companies. The IUP Journal of Corporate Governance, XI(4).

James, L (2013). CSR engagement of Indian companies. International Journal of Social Science \& Interdisciplinary Research, 2(9), 159-171. 
Joreskog, K. G., \& Sorbom, D. (1986). LISREL6 - computer program. Moorseville: IN Scientific Software.

Kaiser, H. F., \& Rice, J. (1974). Little jiffy, mark IV. Educational and Psychological Measurement, 34(1), 111-117.

Kansal, M., \& Singh, S. (2012). Measurement of corporate social performance: An Indian perspective. Social Responsibility Journal, 8(4), 527-546.

Kaplan, R. S. (1984). The evolution of management accounting. The Accounting Review, 59(3), 390-418.

Khan, S. (2008). Corporate Social Responsibility from an Emerging Market Perspective: Evidences from the Indian Pharmaceutical Industry. University of St.Gallen, Business Dissertations. http://www1.unisg.ch/www/edis.nsf/ SysLkpByldentifier/3468/\$FILE/dis3468.pdf.; Accessed on January 11, 2016.

Khan, F.A. (2014). Assessment of mid life career stress of Indian managers. Doctoral Thesis.

Knights, D., \& O'Leary, M. (2006). Leadership, ethics and responsibility to the other. Journal of Business Ethics, 67(2), 125-137.

Kotler, P., \& Lee, N. (2005). Corporate Social Responsibility: doing the most good for your company and your cause (Ist ed.). Hoboken: Wiley.

Krishnan, T. N., \& Poulose, S. (2016). Response rate in industrial surveys conducted in India: Trends and implications. IIMB Management Review, 28(2), 88-97 http://www.sciencedirect.com/science/article/pii/ S0970389616300192\#bib0025. Accessed 2 Oct 2017.

Kuhn, T., \& Deetz, S. (2008). Critical theory and corporate social responsibility: Can/should we get beyond cynical reasoning? In A. Crane, A. McWilliams, D. Matten, J. Moon, \& D. Siegel (Eds.), Oxford handbook of corporate social responsibility (pp. 173-196). Oxford: Oxford University Press.

Kumar, R., Murphy, D., \& Balsari, V. (2001). Altered images: The 2001 state of corporate responsibility in India poll. New Delhi: Tata Energy Research Institute.

Lau, C. M., \& Martin-Sardesai, A. V. (2012). The role of organisational concern for workplace fairness in the choice of a performance measurement system. British Accounting Review, 44(3), 157-172 http://eprints.qut.edu.au/53836/1/ MS_100660__FINAL_VERSION.pdf. Accessed 23 Feb 2015.

Lee, H., Park, T., Moon, H. K., Yang, Y., \& Kim, C. (2009). Corporate philanthropy, attitude toward corporations, and purchase intentions: A South Korea study. Journal of Business Research, 62, 939-946.

Ligeti, G., \& Oravecz, A. (2009). CSR communication of corporate enterprise in Hungary. Journal of Business Ethics, 84, 137-149.

Malhotra, N. K. (2007). Marketing research an applied orientation. Pearson Education India.

McGuire, J. B., Schneeweiss, T., \& Branch, B. (1990). Perceptions of firm quality: A cause or result of firm performance? Journal of Management, 16, 167-180.

Menon, S., \& Kahn, B. E. (2003). Corporate sponsorships of philanthropic activities: When do they impact perception of sponsor brand? Journal of Consumer Psychology, 13(3), 316-327.

Ministry of Finance. (2013). Government of India. Report of the Inter-Ministerial Committee for Boosting Exports from MSME Sector. http://dgft.gov.in/exim/ 2000/imc-EXPORT-sme.pdf. Accessed 1 June 2015.

Mitra, N. (2015). The why, how and what of CSR communication. Academia, 2.

Mitra, N. (2017). Corporate Social Responsibility: A study of Strategic Management and Performance in Large Indian Firms. Dissertation (Working Paper).

Mishra, S., \& Suar, D. (2010). Does corporate social responsibility influence firm performance of Indian companies? Journal of Business Ethics, 95, 571-601.

Mohan, A. (2001). Corporate citizenship: Perspectives from India. Journal of Corporate Citizenship, 2(Summer), 107-117.

Murphy, P. (1978). An Evolution: Corporate Social Responsiveness. University of Michigan Business Review Nov.

Noland, J., \& Phillips, R. (2010). Stakeholder engagement, discourse ethics and strategic management. International Journal of Management Reviews, 12(1), 39-49.

Page, C., \& Meyer, D. (2000). Applied research Design for Business and Management. Sydney: McGraw Hill.

Peloza, J., \& Papania, L. (2008). The missing link between corporate social responsibility and financial performance: Stakeholder salience and identification. Corporate Reputation Review, 11(2).

Perez, A., \& Rodríguez del Bosque, I. (2013). Measuring CSR image: Three studies to develop and to validate a reliable measurement tool. Journal of Business Ethics, 118, 265. https://doi.org/10.1007/s10551-012-1588-8.

Rath, J. \& Gurtoo, A. (2012). Corporate Social Responsibility Orientation: Theorizing through the Williamson Framework. Vikalpa, 37(2), 9-18.

Rana, S., \& Misra, P. (2010). Operational dimension of CSR: An empirical assessment of BSE and NSE listed companies. Vision, 14, 57-66.
Rettab, B., Brik, A. B., \& Mellahi, K. (2009). A study of management perceptions of the impact of corporate social responsibility on organizational performance in emerging economies: The case of Dubai. Journal of Business Ethics, 89, 371-390.

Roberts, P. W., \& Dowling, G. R. (1997). The value of a Firm's corporate reputation: How reputation helps attain and sustain superior profitability. Corporate Reputation Review, 1 (1 \& 2).

Sagar, P., \& Singla, A. (2004). Trust and corporate social responsibility: Lessons from India. Journal of Communication Management, 8(3), 282-290.

Saxena, M., \& Kohli, A. S. (2012). Impact of corporate social responsibility on corporate sustainability: A study of the Indian banking industry. The IUP Journal of Corporate Governance, XI(4), 39-54.

Schiefelbein, K. (2012). Using the right CSR Communication Strategy: The impact on Consumer Attitude and behaviour. Master Thesis in Communication Studies. University of Twente. http://essay.utwente.nl/62190/1/MSc_K_Schiefelbein. pdf. Accessed 20 Sept 2014.

Scholz, F. W. (1985). Maximum likelihood estimation. Encyclopedia of statistical sciences.

Schwaiger, M. (2004). Components and parameters of corporate reputation - An empirical study. Schmalenbach Business Review, 5, 46-71.

Schwalbach, J. (2000). Image, reputation und Unternehmenswert. In B. Baerns \& R. Juliana (Eds.), Information und Kommunikation in Europa. Forchung und praxis [Transnational communication in Europe. Research and Practice] (pp. 287-297).

Sen, S., \& Bhattacharya, C. B. (2001). Does doing good always lead to doing better? Consumer reactions to corporate social responsibility. Journal of Marketing Research, 38(2), 225-243.

Sen, S., Du, S., \& Bhattacharya, C. B. (2009). Building relationships through corporate social responsibility. In D. J. MacInnis, C. W. Park, \& J. R. Priester (Eds.), Handbook of Brand Relationships (pp. 195-211). Armonk: M.E. Sharpe.

Sethi, B. (2014). CSR - an essential strategic reputation management tool. CSR \& Competitiveness, 1(9), 20.

Shaista, S., \& Sara, J. (2014). Impact of CSR on organizational performance. European Journal of Business and Management.

Shanmugam, K, \& Mohamed, N. S. (2011). A study on CSR initiatives in Indian automobile industry. Interdisciplinary Journal of Contemporany Research in Business, 3(6).

Sharma, A., \& Kiran, R. (2011). Corporate social responsibility in changing markets: New mechanisms and newer initiatives. African Journal of Business Management, 6(16), 5479-5490.

Smith, T. (1995). Trends in nonresponse rates. International Journal of Public Opinion Research, 7, 157-171.

Stanaland, A. J. S., Lwin, M. O., \& Murphy, P. E. (2011). Consumer perceptions of the antecedents and consequences of corporate social responsibility. Journal of Business Ethics, 102, 47-55.

Steiger, J. H. \& Lind, J. (1980). Statistically-based tests for the number of common factors. Paper presented at the Annual Spring Meeting of the Psychometric Society, lowa City, 10.

Superti, C. (2005). Corporate Responsibility - driven towards standardization? Cranfield University at Silsoe Institute of Water and Environment. https://stud. epsilon.slu.se/11021/1/superti_c_170918.pdf. Accessed 6 July 2009.

Ullman, J. B. (2006). Structural equation modeling: Reviewing the basics and moving forward. Journal of personality assessment, 87(1), 35-50.

Visser, W. (2008). Corporate social responsibility in developing countries. In CSR in Global Context (pp. 473-498).

Vuontisjärvi, T. (2006). The European context for corporate social responsibility and human resource management: An analysis of the largest Finnish companies. Business Ethics: An European Review, 15(3), 271-291.

Wang, S. A. (2013). Financial communications: Information processing, media integration, and ethical considerations. Palgrave Macmillan.

Warner, R. M. (2008). Applied statistics: From bivariate through multivariate techniques. Sage Publishing.

Whitley, B. E. (2002). Principles of research in behavioural science. McGraw Hill Publishing.

Yoon, Y., Gürhan-Canli, Z., \& Schwarz, N. (2006). The effect of corporate social responsibility (CSR) activities on companies with bad reputations. Journal of Consumer Psychology, 16(4), 377-390. 